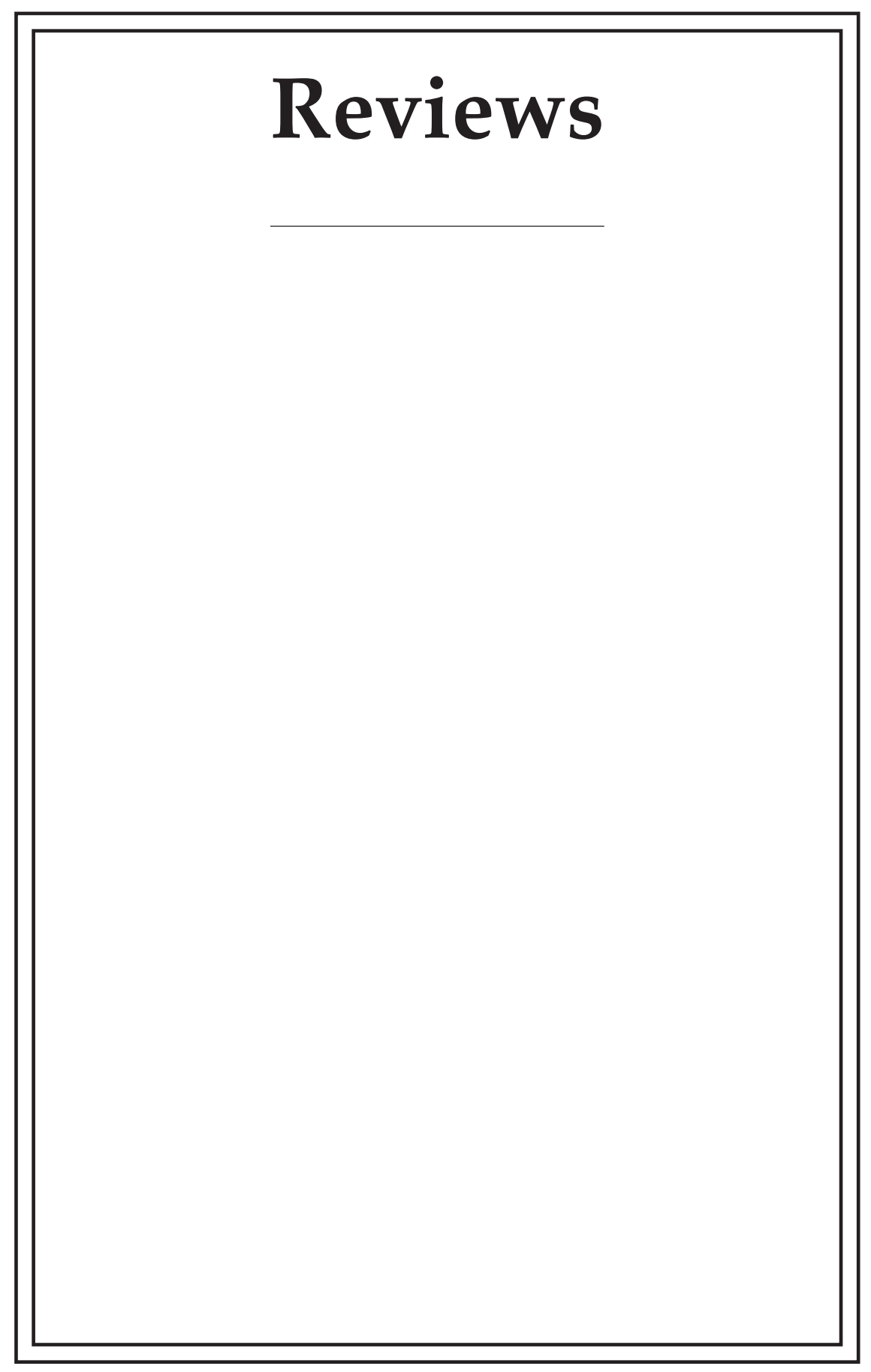

Downloaded from Brill.comఠ4/26/2023 09:53:13AM 


\title{
WHAT WAS THE QUESTION? \\ THE INTER-BYZANTINE DISCUSSIONS \\ ABOUT THE FILIOQUE, NICEPHORUS BLEMMYDES, AND GREGORY OF CYPRUS
}

\begin{abstract}
About a recent book:
La vie et l'auvre théologique de Georges/Grégoire II de Chypre (1241-1290) patriarche de Constantinople, éd. Jean-Claude LARCHET (Théologie byzantine), Paris: Cerf, 2012, 332 p. ISBN 978-2-204-09715-4.
\end{abstract}

This volume, which is edited by one of the leading patristic scholars of our time, Jean-Claude Larchet, is certain to become the standard introduction to the theological work of Gregory of Cyprus - one of the key figures in late Byzantine Orthodox theology. Thus, this volume forms a pendant to the recent two-volume edition [by Michel Stavrou; SC 517 (2007) and 558 (2013)] of the theological works of another such figure, Nicephorus Blemmydes, whose mutual relations with Gregory of Cyprus are, in turn, one of the key problems in the history of this theology.

The importance of Gregory of Cyprus, as a matter of fact, was revealed in the 1950s, due to the pilot studies of the theological predecessors of Gregory Palamas by John Meyendorff. Since then, several more specialised studies have been published, including a historical monograph by Aristide Papadakis (stimulated and influenced by John Meyendorff), in which Gregory of Cyprus is represented principally as a Church leader (1983; $2^{\text {nd }}$ improved ed. 1997; several reprints). However, Papadakis does not go any deeper into theological matters, and his presentation of Gregory's theology is not always especially helpful (as Larchet frequently emphasises in the present book).

I will mention briefly what makes the present volume remarkable for its large audience of Byzantinisants before focussing more specifically on theology.

Part One of the book, written by Larchet himself, is entitled "VieOeuvre-Pensée théologique" (p. 13-127). One can see that this is rather a short monograph - which is very typical for the "introd- 
uctions" to various patristic translations written by Larchet. I would especially recommend ch. II (p. 47-64) which is a useful and up-todate list of Gregory's writings together with their editions and manuscripts. Part Two (p. 129-164) is a philological study of the recently discovered complete text of the main theological treatise of Gregory known until recently (by its publications in Dositheos of Jerusalem's

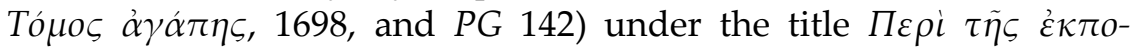

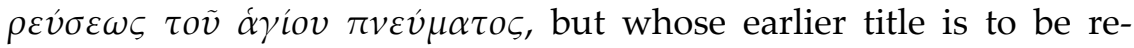

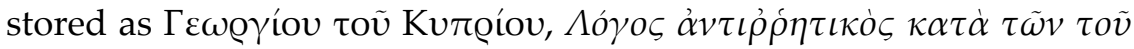

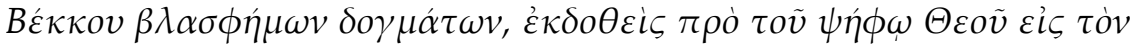

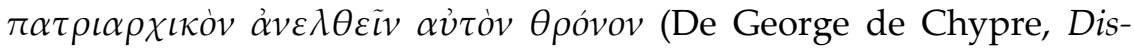
cours antirrhétique des doctrines blasphématoires de Bekkos, publié avant qu'il n'accède au trône patriarchal par decision divine). It is written (in Modern Greek but published in Françoise Vinel's French translation) by the metropolitan of Messina, Chrysostomos (Sabbatos), who discovered this previously overlooked long recension. Metropolitan Chrysostomos has been known for a long time for his studies of the late Byzantine theological authors, but outside Greece his publications attract much less attention than they deserve. This part of the book seems to be a French adaptation of Mgr Chrysostomos' 2003

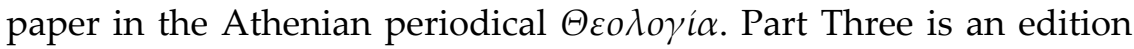
of this newly discovered long recension together with its French translation (by F. Vinel) en regard (p. 165-257). The edition has been prepared "par le hiéromoine Théophile Kislas sur la base des travaux préparatoires du métropolite Chrysostomos Sabbatos." Fr Theophilus (Kislas), a former disciple of Asterios Argyriou in Strasbourg and now an Athonite monk, is especially known for his critical edition of the great treatise On the Procession of the Holy Spirit by Nilus Cabasilas (2001). I think it was a very helpful choice to give him this portion of the collective work. Finally, Part Four (p. 259-311) contains French translations of the four remaining theological works of Gregory (one by Larchet, the three others by Vinel), and Part Five (p. 313-327) the bibliography (Larchet).

Now, let us turn to theology, namely, to ch. III of Part One (p. 65127). The major question is, of course, the exact positioning of Gregory between Blemmydes and Palamas, but the author also extends his attention beyond this frame, consecrating short paragraphs to other late Byzantine authors. Larchet's paragraph on George Moschampar (p. 87-88; cf. also other mentions of Moschampar in this chapter) is worth noting as the first acknowledgement of the importance of this 
author in modern historiography. Moschampar belonged to the conservative opposition to Gregory of Cyprus but Larchet distinguishes him from the milieu of "traditionalisme formaliste;" indeed, Moschampar had some original ideas about the possibility of an Orthodox interpretation of the Filioque, and so, Larchet's distinction looks justified. At least, Moschampar was a disciple of Nicephorus Blemmydes,

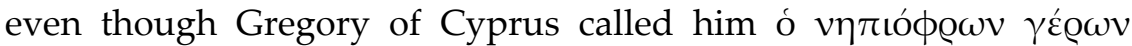
(Ep. LXXVIII acc. to S. Eustratiadès' 1908-1910 publication, AD 1289). According to my own (as yet superficial) observations and intuition, it is Moschampar who was the most important "anti-Palamite" (if I can permit myself to use such an anachronism) theologian of the epoch. This theology, directly or indirectly, would become one of the main sources of both argumentation and inspiration for Akyndinos who quotes several times, under the name of St Photius, some otherwise unknown texts which look as though they were written against Gregory of Cyprus' ideas. It would then be revived, in the late $16^{\text {th }}$ cent., by Meletius Pegas during his intervention into the polemic between Gabriel Severus and Maximus Margounios about the procession of the Holy Spirit, which lead to a quasi-canonisation of the de facto anti-Palamite triadology in the "Orthodox" scholastics from the $17^{\text {th }}$ to the $19^{\text {th }}$ centuries. I have dared here to formulate my working hypothesis about Moschampar's relevance as an invitation to other scholars to study his works properly. It is, unfortunately, symptomatic that Moschampar's opus magnum, $\Delta \iota \alpha \dot{\lambda} \lambda \varepsilon \xi \iota \varsigma \mu \varepsilon \tau \alpha \dot{\alpha} \tau \iota v o \varsigma ~ \pi \varepsilon \rho \delta \iota k \alpha-$

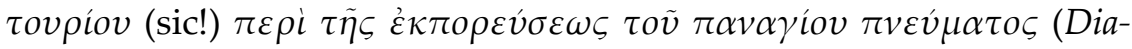
logue with a Certain Dominican about the Procession of the All-Holy Spirit, 1277/78), has never been studied by historians of theology and is not even mentioned by Larchet either (although he quotes, of course, V. Laurent's seminal 1929 paper on Moschampar). This work was published only partially (20 chapters out of 52) under the name of Maximus Margounios in a very rare edition - the first Greek book printed in the Greek lands - in 1627 in Constantinople by the Greek printing pioneer Nicodemos Metaxas (this book has no title common to its three parts, and the part containing Moschampar's work is not present in all copies). Moreover, Chrysostomos (Sabbatos), then archimandrite, published Moschampar's short work that should be mentioned, at least, in the notes to the translation of Gregory of Cy-

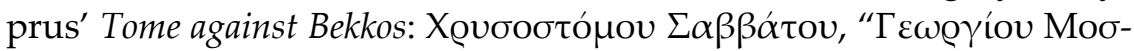

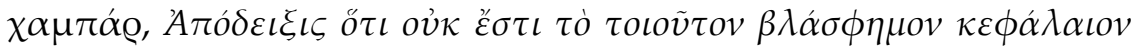

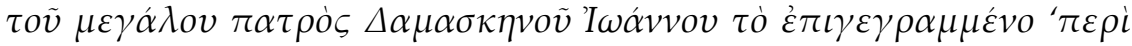




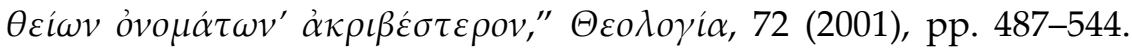
Moschampar here argues (not in agreement with Bonifatius Kotter) that John of Damascus' chapter quoted by Gregory of Cyprus is falsified by some heretics.

Larchet's comparison between Gregory of Cyprus and Gregory Palamas leads to intuitively predictable conclusions: "Palamas s'est moins inspire de Grégoire de Chypre qu'on ne l'a prétend, notamment parce que sa base de réflexion est plus étendue que la sienne et que son contexte est pour une large part différent, même si Palamas inaugura son œuvre théologique par une réflexion sur le Filioque qui n'ignorait plus celle du Chypriote" (p. 126). Indeed, the theological works of the former Gregory are limited to one synodal Tomos (1285) and the most acute years of the polemic that it provoked (from 1285 to 1289). Unlike Palamas, Gregory of Cyprus was a prolific "humanist" author and hagiographer, who, after having become patriarch, was only intermittently forced to write on theology. His theological explanations are always limited to the very restricted needs of maintaining control over the patriarchate (a goal at which he eventually failed).This is not to say, however, that a more detailed comparison between the two Gregories would not reveal something more unexpected; we will return to this below.

The crux interpretum is, of course, the comparison between Gregory of Cyprus and Nicephorus Blemmydes. To some extent, one can notice a partial agreement between Larchet, on the one hand, and Michel Stavrou and myself, on the other. We all agree that the theology of Blemmydes was open to development in both directions, either in that of John Bekkos or that of Gregory of Cyprus. Now Larchet elaborated on this point in a more detailed way in his review of the $2^{\text {nd }}$ tome of Stavrou's edition of Blemmydes [Revue d'histoire ecclésiastique 109 (2014), pp. 322-327]. Moreover, I have to acknowledge that Larchet is right in his criticism as "évidemment tout à fait abusif" of my 1997 claim that Palamas could be considered as a "disciple" of Gregory of Cyprus (p. 111, n. 173). This was an exaggeration. However, Larchet is far from sharing our (mine and Stavrou's) evaluation of Blemmydes' theological work as not an “...évolution mais approfondissement ou involution de la pneumatologie byzantine" [Stavrou's words (SC 517, p. 117) which I have undersigned in my review, Scr 5 (2009), pp. 425-429 (426)]. To Larchet, Blemmydes' theology was not especially unorthodox but too imprecise and even confused, in contrast to the theological doctrine of Gregory of Cyprus 
which was limited by its contents but precise and also, a fortiori, in contrast to the multidimensional theological synthesis of Gregory Palamas.

Apparently, the things look like this - at least, at the first approximation. This "first approximation" is the only level taken into account by Larchet. It implies that the most fundamental notions

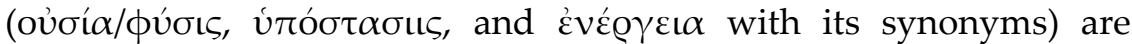
well-defined and must be as clear to our mediaeval authors as they are clear to Larchet. This is why Larchet has no hesitation in detecting where Blemmydes confuses hypostasis and energy. For Gregory Palamas and his followers in the middle of the "hesychast quarrels," however, these things were not so evident. This lead, in the middle of the fourteenth century, to the appearance of the short-living phenomenon of the "hesychast" triadology which I described long ago but without any analysis. ${ }^{1}$ This phenomenon consists of a non-standard explanation of the significance of Pentecost. The Spirit received by the apostles on that day was always interpreted, before Palamas, as the hypostasis of the Spirit. This was the attitude of the Byzantine Fathers both before and after the beginning of the Filioque polemic. Since Gregory Palamas, still during his lifetime, we see another interpretation: the gift of the Spirit at the day of Pentecost was not the hypostasis but only the energies. The difference between Pentecost and the previous Gospel scene related to the donation of Spirit, John 20:20-23 (traditionally understood as the donation of the energies but not the hypostasis of the Spirit), was thus reconsidered so as to be the donation of only one gift (energy) of the Spirit, that of forgiving the sins, in contrast with Pentecost which is the donation of all gifts of the Spirit. Such an exegesis was too much at odds with the whole tradition to become adopted by the later, even Palamist, defenders of Orthodoxy.

The problem worrying Gregory Palamas was clear: the gift of the hypostasis of the Spirit, in his terminology, would mean some kind of communication to the incommunicable divine nature (according to the standard definition of hypostasis as oúoí $\alpha \varepsilon \tau \dot{\alpha} \tau \tilde{\omega} v \dot{\alpha} \phi o \varrho ı \sigma-$ $\tau \iota \kappa \tilde{\omega} \nu i \delta \iota \omega \mu \alpha \dot{\tau} \tau \omega \nu)$. This theological problem was eventually resolved within the theological system of Palamas taken as a whole, and this is why the later Palamites were able to return to the traditional exegesis

(1) B. LOURIÉ, “L'attitude de S. Marc d'Ephèse aux débats sur la procession du Saint-Esprit à Florence. Ses fondements dans la théologie postpalamite," Annuarium Historiae Conciliorum, 21 (1989 [ed. 1991]), pp. 317-333. 
of Pentecost and John 20:20-23. Palamas' resolution was found on the roads paved by Dionysius the Areopagite with his paraconsistent logic. ${ }^{2}$ This logical meta-language of Palamas, borrowed in Dionysius both directly and through Maximus the Confessor, is the logical skeleton of his theological system. This allowed Palamas to proceed through paraconsistent conjunctions of mutually contradictory claims (e. g., that the nature of God is both incommunicable and communicable according to 2 Pet 1:4).

In fact, this paraconsistency was implied in the notion of hypostasis from the very beginning, right from the time of the Cappadocian Fathers in the fourth century. Thus, the whole system of mutually dependent notions of hypostasis, essence/nature, and energy became paraconsistent, too. The later development of the Christological and Triadological discussions has, since then, been oscillating around the fundamental paraconsistency of the logical apparatus and various attempts at overcoming it. ${ }^{3}$ From a logical point of view, the history of the dogmatic polemics from the fourth century onwards looks somewhat similar to the recent history of the "naïve" set-theory (which is paraconsistent, too), in which the roles of Zermelo, Fraen-

(2) P. ROJEK, "Logic of Palamism," in: Logic in Orthodox Christian Thinking, ed. A. SCHUMANN, Heusenstamm, 2013, pp. 38-80, provides a consistent logical reconstruction, but it leads, without the knowledge of the author, to the distorted image of Palamas created by Barlaam and Akyndinos, that is, as somebody who acknowledges two different kinds of divinity calling them "essence" and "energy." The author provides a modal formula (ibid., p. 61) whose meaning is "[n]ecessarily, if there is energy, then there is also essence, and not necessarily, if there is essence, there is energy," but this formula "expresses... in proper modal terms" rather a blatant error of its author than "the ontological dependency" between the essence and the energy. In fact, as "the movement of the essence" (according to one of the standard definitions unknown to Rojek), the energy could never have been separated from the essence.

(3) Cf. B. LouRIÉ, "Leontius of Byzantium and His 'Theory of Graphs' against John Philoponus," in: The Ways of Byzantine Philosophy, ed. M. KNEŽEVIĆ, Alhambra, CA, 2014 (in print); as a more general introduction (especially concerning the difference between essence and energy), s. IDEM, "The Philosophy of Dionysius the Areopagite: An Approach to Intensional Semantics," in: Georgian Christian Thought and Its Cultural Context. Memorial Volume for the 125 th Anniversary of Shalva Nutsubidze (1888-1969), ed. T. NuTSUBIDZE, C. B. HORN, B. LOURIÉ, with the Collaboration of A. OsTROVSKY (Texts and Studies in Eastern Christianity), Leiden, Boston, 2014, pp. 81-127. 
kel, Quine and all those who tried to free the "naïve" theory from its paradoxes are played by different opponents of the Byzantine patristic tradition.

It is not the place here to go any deeper into these matters, and so I will provide only one illustration. No consistent definition of hypostasis or energy implies a fundamental feature of both, namely, that of being a part which contains the whole (that is, the indivisible divisibility of God). In modern logic, somewhat similar objects became known through Dedekind and Cantor's infinite sets, where, by definition, the power of the set (or the number of elements of a countable infinite set) is not affected by its divisions. Therefore, turning back to natures, hypostases, and energies, we are always confronted with a dilemma: either we use consistent definitions but in an inconsistent way (by analogy with the so-called Principle of Correspondence formulated by Niels Bohr for the Copenhagen interpretation of Quantum mechanics) or we tolerate an explicit inconsistency even on the level of definitions. The latter alternative is that of Dionysius the Areopagite (for nature and energies) and Eulogius of Alexandria (preserved in Photius' abstract only) and Theodore the Studite (for hypostasis), but normally the Byzantine Fathers used the consistent definitions (especially that of hypostasis) in an inconsistent way. "Inconsistent" and especially "paraconsistent" does not mean "chaotic" or "arbitrary" (in paraconsistent logic, the principle ex contradictione quodlibet does not work). However, a failure to provide a systematic but paraconsistent interpretation has the potential to result in the obfuscation of certain conceptions (cf. the above example of the Palamite exegesis of the Pentecost).

The internal meaning of the Filioque quarrels was also the same. On their deepest level, they, too, were about the nature and the hypostasis rather than the procession of the Holy Spirit as such (as we have recently formulated in a private discussion with Dirk Krausmüller on Symeon the New Theologian and Nicetas Stethatos).

Although Larchet is able to catch Blemmydes' implicit deviations from the textbook consistent definitions, Blemmydes seems to be more sensible than Larchet to the paraconsistent nature of the concepts he deals with. Unlike Gregory of Cyprus, Blemmydes, in his two major theological epistles, discusses the delicate topic with his competent friends; he is not preoccupied with any pressing practical needs to find out or defend a synodal definition. Any such definition is, by necessity and due to the laws of the genre, a simplification or, 
better, a particular resolution, for given values of most variables, of a multivariable equation.

Blemmydes, however, discusses the problem as it is, allowing no simplification. In this context, he became able to find out a formula which simultaneously blocks Bekkos' latinophronic interperation and clarifies what both Gregory of Cyprus and Gregory Palamas left obscure: "si le Verbe et l'Esprit <existent> à partir du Père comme du

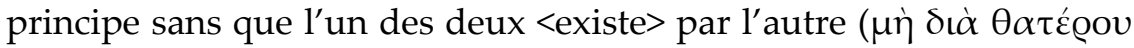

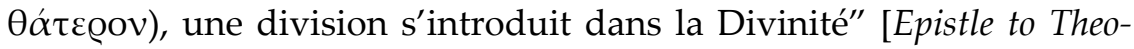
dore Laskaris, 10; t. I, p. 346 (txt) /347 (tr.) Stavrou].

Bekkos' interpretation is here blocked because of the highly symmetrical nature of the formula: any interpretation of $\delta \iota^{\prime}$ Yiou is acceptable only in the sense that it would also be correct to say that the Son is generated "through/by the Spirit." No Latin triadology, neither that of the Libri Carolini (that considered the Father and the Son as two different sources of the Spirit) nor the tanquam ab uno principio theology of the Council of Lyon (1274) would agree with this. Both Gregory of Cyprus and Gregory of Palamas left without any explicit answer a rather natural question: why, if we can speak about the proceeding of the Spirit through the Son, cannot one say that the Son is begotten through the Spirit? Blemmydes is perfectly clear: we can, although not in the sense of the Spirituque of the modernist nominally Orthodox theologians of the twentieth century (which would imply a hypostatic generation analogous to the Filioque in the Latin sense), ${ }^{4}$ but in the same "energetical" meaning as that of the synodal decision of 1285 and of Gregory Palamas. Namely, an interpretation of the generation of the Son as effectuated "through the Spirit" is not only allowable but obligatory, although in an "energetical" sense analogous to the "energetical" interpretation of the Filioque put forward at the Constantinopolitan Synod of 1285.

One can see from this protracted discussion how thought-provoking this work of Larchet and his collaborators is. It presents by itself an important achievement in the study of late Byzantine theology but it also opens a door to further achievements.

B. Lourié

Saint Petersburg State University of Aerospace Instrumentation

(4) As Stavrou demonstrated (in his introduction to the t. I of Blemmydes; cf. my review). 